\title{
9
}

\section{Allgemeines zu Swapgeschäften}

\section{Bewertung eines Swapgeschäftes}

Fairer Wert eines Swaps mit vereinbartem Tausch von Zahlungsströmen während der Laufzeit und bei Abschluss

Wert des Swaps $=$ Barwert des zu erhaltenden Zahlungsstroms

- Barwert des zu leistenden Zahlungsstroms 